\title{
Investigation of the durability of a poly-p-phenylenediamine/carbon black composite for the oxygen reduction reaction
}

\author{
Xiaogang Su ${ }^{a, b}$, Yingfang Yao ${ }^{a, b, c}$, Juan Tianc c, Jianguo Liu ${ }^{a, b, c, d, *}$, Zhongwei Wang a,b, Yong You ${ }^{a, b}$, \\ Lin Huang a,b,c, Congping Wu a a,b,c \\ ${ }^{a}$ College of Engineering and Applied Sciences, Nanjing University, Nanjing 210093, Jiangsu, China \\ b National Laboratory of Solid State Microstructures, Collaborative Innovation Center of Advanced Microstructures, Nanjing University, Nanjing 210093, \\ Jiangsu, China \\ c Kunshan Innovation Institute of Nanjing University, Suzhou 215347, Jiangsu, China \\ d Suzhou High-Tech Institute of Nanjing University, Suzhou 215123, Jiangsu, China
}

\section{A R T I C L E I N F O}

Article history:

Received 6 January 2016

Accepted 2 February 2016

Published 5 July 2016

\section{Keywords:}

Phenylenediamine

Carbon black

Composite structure

Oxygen reduction reaction

Durability

\begin{abstract}
A B S T R A C T
Nitrogen-doped carbon materials exhibiting high oxygen reduction reaction activity were prepared via the pyrolysis of a poly- $p$-phenylenediamine/carbon black composite. The as-synthesized catalyst showed excellent catalytic activity in alkaline solution, and outperformed commercial $\mathrm{Pt} / \mathrm{C}$ in $\mathrm{KOH}$ solution $(0.1 \mathrm{~mol} / \mathrm{L})$, as demonstrated by the higher current density and the more positive half-wave potential. Scanning electron microscopy and $\mathrm{N}_{2}$ adsorption-desorption analyses indicated that a composite structure, in which the N-rich surface of the poly- $p$-phenylenediamine had an increased active center concentration and the high external surface area of the carbon black was conducive to the mass transport, is highly beneficial in terms of promoting the oxygen reduction reaction. However, the activity of this catalyst underwent an obvious decrease following exposure to air for $30 \mathrm{~d}$. X-ray photoelectron spectroscopy showed that the oxygen content in the catalyst was increased by prolonged air exposure. $01 s$ spectrum showed increases in the $\mathrm{C}=\mathrm{O}$ and $\mathrm{C}-\mathrm{O}$ components, suggesting that atmospheric oxygen reacted with the catalyst. This oxidation leaded to the deactivation of active center, thus the catalytic activity decreased. Based on these results, the stability in air of nitrogen-doped carbon materials must be taken into consideration when assessing applications as alternatives to platinum-based materials.
\end{abstract}

(C) 2016, Dalian Institute of Chemical Physics, Chinese Academy of Sciences. Published by Elsevier B.V. All rights reserved.

\section{Introduction}

The oxygen reduction reaction (ORR) is a crucial process in many energy conversion devices, such as fuel cells and metal/air batteries [1]. Although platinum-based materials have proven to be the most efficient catalysts for the ORR, the high cost and scarcity of this metal significantly hinder the large-scale applications of these devices [2,3]. Recently, non-precious metal and metal-free ORR catalysts have attracted significant research interest as alternatives to plati-

\footnotetext{
*Corresponding author. Tel: +86-25-83621219; E-mail: jianguoliu@nju.edu.cn

This work was supported by the National Natural Science Foundation of China (21476104), the Natural Science Foundation for Distinguished Young Scholars of Jiangsu Province (BK20150009), the Natural Science Foundation for Young Scholars of Jiangsu Province (BK20150396), the Soft Science Research Program of Jiangsu Province (BR2015009), the Nanotechnology Program of Suzhou (ZXG2013029), the Priority Academic Program Development (PAPD) of Jiangsu Higher Education Institutions, Qing Lan Project of Jiangsu Province, and the Fundamental Research Funds for the Central Universities, China.
}

DOI: 10.1016/S1872-2067(15)61063-4 | http://www.sciencedirect.com/science/journal/18722067 | Chin. J. Catal., Vol. 37, No. 7, July 2016 
num-based compounds [4,5]. Nitrogen-doped carbon materials represent typical metal-free catalysts and exhibit excellent ORR activity as the result of nitrogen incorporation, as confirmed by experimental studies and quantum mechanical calculations [6-8]. Aniline derivatives have unique structures consisting of aromatic rings connected via imino groups, and so are frequently used as the nitrogen source in nitrogen-doped carbon materials [9-12]. However, a remaining challenge associated with these catalysts is their insufficient durability. The electrochemical stability and durability in air of nitrogen-doped carbon materials are substantially lower than those of platinum-based compounds, and this has hampered their applications $[4,13]$. Many groups have reported on the electrochemical stability of nitrogen-doped carbon materials, and great progress has been made in this respect over the past several years $[4,14]$. However, there have been few reports of the durability in air of nitrogen-doped carbon materials.

Platinum-based materials exhibit excellent ORR activity because of their appropriate oxygen binding and $\mathrm{OH}$ bonding energy values $[15,16]$. During the ORR, oxygen is eventually reduced to water as electrons flow through an external circuit to the anode. However, when platinum-based catalysts are exposed to air, this electrochemical reaction does not proceed $[17,18]$. Because the adsorption of atmospheric oxygen on the Pt surface generates an oxide coating [19], platinum-based catalysts must undergo an activation treatment to remove the surface oxidation layer before they exhibit optimal performance [20]. In the case of nitrogen-doped carbon materials, oxygen also adsorbs on the surface of the catalyst during the ORR $[8,21]$. This raises the question of whether or not oxygen will react with the catalyst and, if so, how this impacts the catalytic activity.

Herein, we report a poly- $p$-phenylenediamine (PpPD)/carbon black (CB) composite catalyst that shows high ORR activity, such that it outperforms a commercially available Pt/C catalyst (10\% Pt, Johnson Matthey Corp) in $\mathrm{KOH}$ solution (0.1 mol/L). More importantly, we demonstrate that the exposure of the composite to air results in a reaction between oxygen and the catalyst, leading to a decrease in the ORR activity.

\section{Experimental}

\subsection{Chemicals and apparatus}

Both $p$-phenylenediamine (AR, 97\%) and ammonium persulfate (AR, $\geq 98 \%$ ) were purchased from the Aladdin company (Shanghai, China) and were used without further purification. All the electrochemical experiments were carried out using a Parstat 2273 electrochemical station. Scanning electron microscopy (SEM) images were obtained with a Nova NanoSEM 230 and $\mathrm{N}_{2}$ adsorption-desorption isotherms were acquired with a Micromeritics Tristar 3000 analyzer at $-196{ }^{\circ} \mathrm{C}$. X-ray photoelectron spectroscopy (XPS, ESCALAB 250) was used to characterize the surface compositions of the samples.

\subsection{Preparation of catalysts}

To prepare composites consisting of $\mathrm{P} p \mathrm{PD}$ and $\mathrm{CB}$ (Black Pearls 2000) (termed 0.44P $p$ PD/CB, 0.88P $p$ PD/CB and $1.32 \mathrm{P} p \mathrm{PD} / \mathrm{CB}), p$-phenylenediamine $(0.44,0.88$ or $1.32 \mathrm{~g})$ was dissolved in $200 \mathrm{~mL}$ deionized water, following which $0.5 \mathrm{~g} \mathrm{CB}$ was added. After stirring for $5 \mathrm{~h}$, a solution of the oxidant $\left(\mathrm{NH}_{4}\right)_{2} \mathrm{~S}_{2} \mathrm{O}_{8}$ was added dropwise. The polymerization was allowed to proceed first with the container immersed in an ice bath $\left(0{ }^{\circ} \mathrm{C}\right)$ for $6 \mathrm{~h}$, and then at room temperature for another $18 \mathrm{~h}$. The resulting products were filtered and washed with deionized water, then dried at $60^{\circ} \mathrm{C}$. Finally, the mixtures were ground into powder and heated under a $\mathrm{N}_{2}$ flow at $1000{ }^{\circ} \mathrm{C}$. A sample of pure $\mathrm{P} p \mathrm{PD}$ was prepared in the same manner, but without adding CB.

\subsection{Characterization of catalysts}

The electrochemical characterization of specimens was carried out in a standard three-electrode cell using a Pt plate counter electrode and a $\mathrm{Ag} / \mathrm{AgCl} / \mathrm{KCl}(3 \mathrm{~mol} / \mathrm{L})$ reference electrode $(0.197 \mathrm{~V}$ vs. $\mathrm{NHE})$ at $25^{\circ} \mathrm{C}$. In brief, the catalyst was dispersed in an ethanol/Nafion (5\%) mixture and ultra-sonicated for $30 \mathrm{~min}$ to form a uniform black ink. This well-dispersed catalyst ink was applied to a pre-polished glassy carbon disk (5 mm diameter, $0.19625 \mathrm{~cm}^{2}$ area) and dried at room temperature. The ORR was performed in $\mathrm{O}_{2}$-saturated $\mathrm{KOH}$ solution $(0.1 \mathrm{~mol} / \mathrm{L})$ with a rotating-disk electrode (RDE) system. The accelerated durability trials were carried out by acquiring cyclic voltammograms $(-0.3 \mathrm{~V}$ to $0.2 \mathrm{~V})$ at $50 \mathrm{mV} / \mathrm{s}$ in $\mathrm{O}_{2}$-saturated $\mathrm{KOH}$ solution $(0.1 \mathrm{~mol} / \mathrm{L})$. All potentials were reported versus $\mathrm{Ag} / \mathrm{AgCl} / \mathrm{KCl}$ (3 mol/L).

\section{Results and discussion}

\subsection{SEM and $N_{2}$ adsorption-desorption tests}

The SEM image in Fig. 1(a) shows that the PpPD had an irregular sheet-like morphology with a smooth surface, and that the particle sizes of the P $p$ PD were on the micrometer scale. The SEM image of the $0.88 \mathrm{P} p \mathrm{PD} / \mathrm{CB}$ (Fig. 1(b)) reveals that the CB particles aggregated on the surface of the P $p$ PD, and that the size of the P PPD sheets was decreased [22]. The composite structure seen here is different from previously reported structures, in which the CB particles were covered with a PpPD shell $[12,23]$. This difference is the result of variations in the process used to polymerize the $p P D$. In the present work, the polymerization was conducted without adding hydrochloric
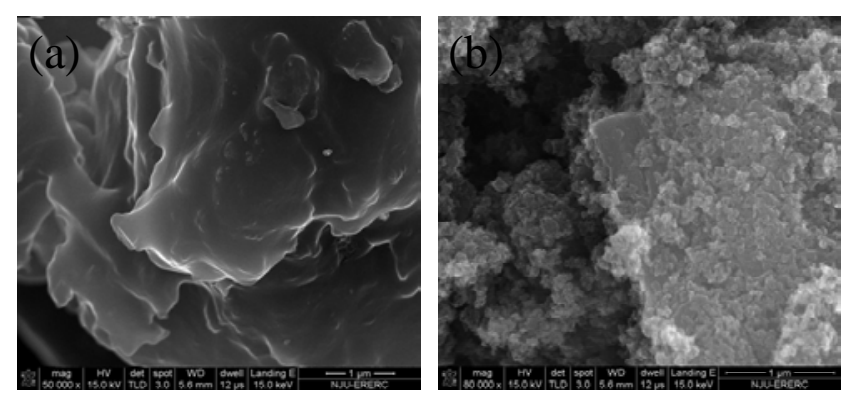

Fig. 1. SEM images of $\mathrm{P} p \mathrm{PD}(\mathrm{a})$ and $0.88 \mathrm{P} p \mathrm{PD} / \mathrm{CB}(\mathrm{b})$. 
acid, thus the water solubility of the undoped P $p$ PD was very low [24]. As a result, the PpPD sheets tended to agglomerate, thus increasing the particles size. Because the interaction between the hydrophobic surfaces of the $\mathrm{CB}$ and the $\mathrm{PpPD}$ is strong, the CB particles also aggregated on the P $p$ PD surfaces and retarded the polymerization reaction. Thus, the P $p$ PD particle sizes in the $0.88 \mathrm{P} p \mathrm{PD} / \mathrm{CB}$ were smaller than in the pure $\mathrm{P} p \mathrm{PD}$ sample. To gain further insight into the structure of the $\mathrm{P} p \mathrm{PD} / \mathrm{CB}$ composites, $\mathrm{N}_{2}$ adsorption-desorption measurements were carried out. Fig. 2(a) shows the adsorption-desorption isotherms, while the corresponding pore size distributions are presented in Fig. 2(b) and the results are summarized in Table 1. As expected, the Brunauer-Emmett-Teller (BET) surface area of the CB was very large, while the BET surface area of the $\mathrm{P} p \mathrm{PD}$ was only $125 \mathrm{~m}^{2} / \mathrm{g}$, which is in good agreement with the image in Fig. 1(a). Therefore, the BET surface area of the $\mathrm{P} p \mathrm{PD} / \mathrm{CB}$ composite decreased as the amount of $\mathrm{P} p \mathrm{PD}$ increased. It is interesting to observe that the micropore area of the $0.88 \mathrm{P} p \mathrm{PD} / \mathrm{CB}$ was larger than that of the $0.44 \mathrm{P} p \mathrm{PD} / \mathrm{CB}$. This occurred because both the $\mathrm{P} p \mathrm{PD}$ and the $\mathrm{CB}$ contributed to the micropore area, thus the $0.88 \mathrm{P} p \mathrm{PD} / \mathrm{CB}$ had a superior composite structure because it contained the optimal ratio of $\mathrm{PpPD}$ to $\mathrm{CB}$.

\subsection{Electrochemical characterization}

We performed RDE measurements in $\mathrm{KOH}$ solution $(0.1$ mol/L) to evaluate the ORR activity of the prepared catalysts. As shown in Fig. 3(b), the onset potential of the PpPD was rather high, and its current density increased slowly as the potential decreased (Fig. 3(a)). This is attributed to the very low BET surface area of the PpPD (with an external surface area of only $12.7 \mathrm{~m}^{2} / \mathrm{g}$ ), because surface area is vital to mass transport in this system. Thus, the current density obtained from the $\mathrm{P} p \mathrm{PD}$ was $2.2 \mathrm{~mA} / \mathrm{cm}^{2}$ even at $-1 \mathrm{~V}$, and a plateau appeared at approximately $-0.5 \mathrm{~V}$, suggesting the production of $\mathrm{HO}_{2}{ }^{-}$. As a result of the addition of $\mathrm{CB}$, the $\mathrm{P} p \mathrm{PD} / \mathrm{CB}$ composite exhibited a substantial improvement in ORR activity and the plateau disappeared. As shown in Fig. 3(a), the ORR activity of the $0.88 \mathrm{P} p \mathrm{PD} / \mathrm{CB}$ was far superior to those of the $0.44 \mathrm{P} p \mathrm{PD} / \mathrm{CB}$ and $1.32 \mathrm{P} p \mathrm{PD} / \mathrm{CB}$. Because these catalysts were all prepared in

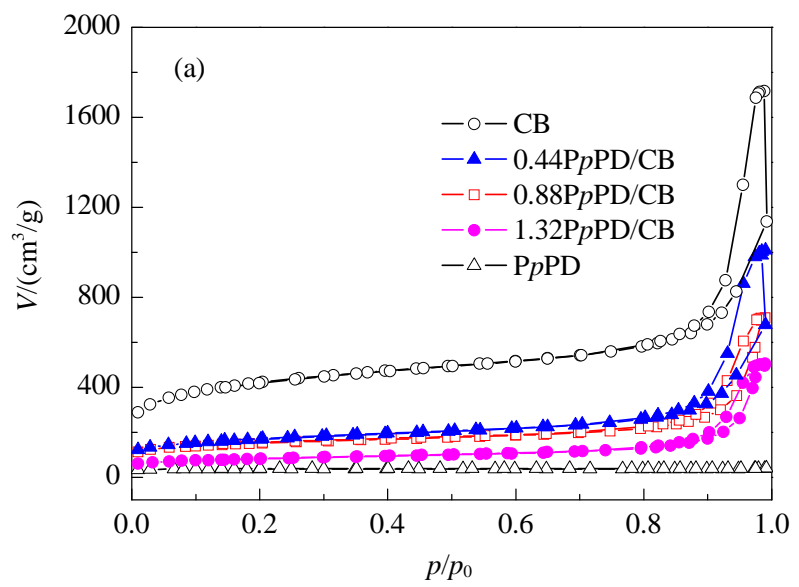

Table 1

BET surface, micropore and external surface areas of the prepared catalysts.

\begin{tabular}{lccc}
\hline Catalyst & $\begin{array}{r}\text { BET surface area } \\
\left(\mathrm{m}^{2} / \mathrm{g}\right)\end{array}$ & $\begin{array}{c}\text { Micropore area } \\
\left(\mathrm{m}^{2} / \mathrm{g}\right)\end{array}$ & $\begin{array}{c}\text { External surface } \\
\text { area }\left(\mathrm{m}^{2} / \mathrm{g}\right)\end{array}$ \\
\hline $\mathrm{P} p \mathrm{PD}$ & 125 & 122 & 12.7 \\
$1.32 \mathrm{P} p \mathrm{PD} / \mathrm{CB}$ & 286 & 127 & 158 \\
$0.88 \mathrm{P} p \mathrm{PD} / \mathrm{CB}$ & 523 & 263 & 260 \\
$0.44 \mathrm{P} p \mathrm{PD} / \mathrm{CB}$ & 590 & 247 & 342 \\
$\mathrm{CB}$ & 1480 & 618 & 862 \\
\hline
\end{tabular}

the same manner, except for the amount of $p$-phenylenediamine, the differences in catalytic activity must have resulted primarily from variations in their physical properties, rather than their chemical characteristics. As noted above, the $0.88 \mathrm{P} p \mathrm{PD} / \mathrm{CB}$ had an advanced composite structure, in which the N-rich surface of the P $p$ PD had an increased active center concentration and the high external surface area of the $\mathrm{CB}$ was conducive to the transport of oxygen and products. Thus the $0.88 \mathrm{P} p \mathrm{PD} / \mathrm{CB}$ outperformed the commercial $\mathrm{Pt} / \mathrm{C}$ catalyst, as demonstrated by the higher current density $(2.17$ $\mathrm{mA} / \mathrm{cm}^{2}$ at $-0.1 \mathrm{~V}$, compared to $1.11 \mathrm{~mA} / \mathrm{cm}^{2}$ for the $\mathrm{Pt} / \mathrm{C}$ ) and the more positive half-wave potential $\left(E_{1 / 2}\right)$.

To gain further insights into the electron transfer kinetics of the ORR over the $0.88 \mathrm{P} p \mathrm{PD} / \mathrm{CB}$, we studied the reaction kinetics by rotating-disk voltammetry. The voltammetric profiles in $\mathrm{O}_{2}$-saturated $\mathrm{KOH}$ solution $(0.1 \mathrm{~mol} / \mathrm{L})$ show that the current density was enhanced as the rotation rate increased from 400 to $2000 \mathrm{r} / \mathrm{min}$ (Fig. 3(c) inset) [25], and the corresponding Koutecky-Levich plots $\left(J^{-1}\right.$ vs. $\left.\omega^{-1 / 2}\right)$ at various potentials exhibit good linearity. In alkaline solution, the ORR generally proceeds by one of two pathways. The first is a direct 4-electron process in which $\mathrm{O}_{2}$ is reduced to $\mathrm{OH}^{-}$, while the other is a 2-electron reduction pathway such that the $\mathrm{O}_{2}$ is reduced to $\mathrm{HO}_{2}{ }^{-}$, followed by further reduction of the $\mathrm{HO}_{2}{ }^{-}$[26]. We supposed that the ORR over Pt/C proceeded via the 4-electron reaction at $-0.4 \mathrm{~V}$, and calculated the number of electrons transferred at various electrode potentials of $\mathrm{Pt} / \mathrm{C}$ and $0.88 \mathrm{P} p \mathrm{PD} / \mathrm{CB}$. In the case of the $0.88 \mathrm{P} p \mathrm{PD} / \mathrm{CB}$, the number of electrons transferred at various electrode potentials was constant at approximately 3.6 (Fig. 3(c)), suggesting that $\mathrm{O}_{2}$ is

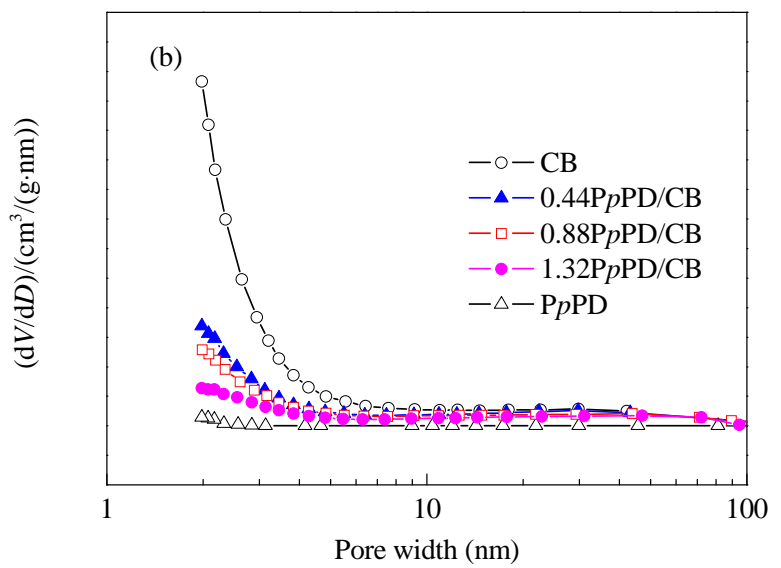

Fig. 2. $\mathrm{N}_{2}$ adsorption-desorption isotherms (a) and the corresponding pore size distributions (b) of the prepared catalysts. 

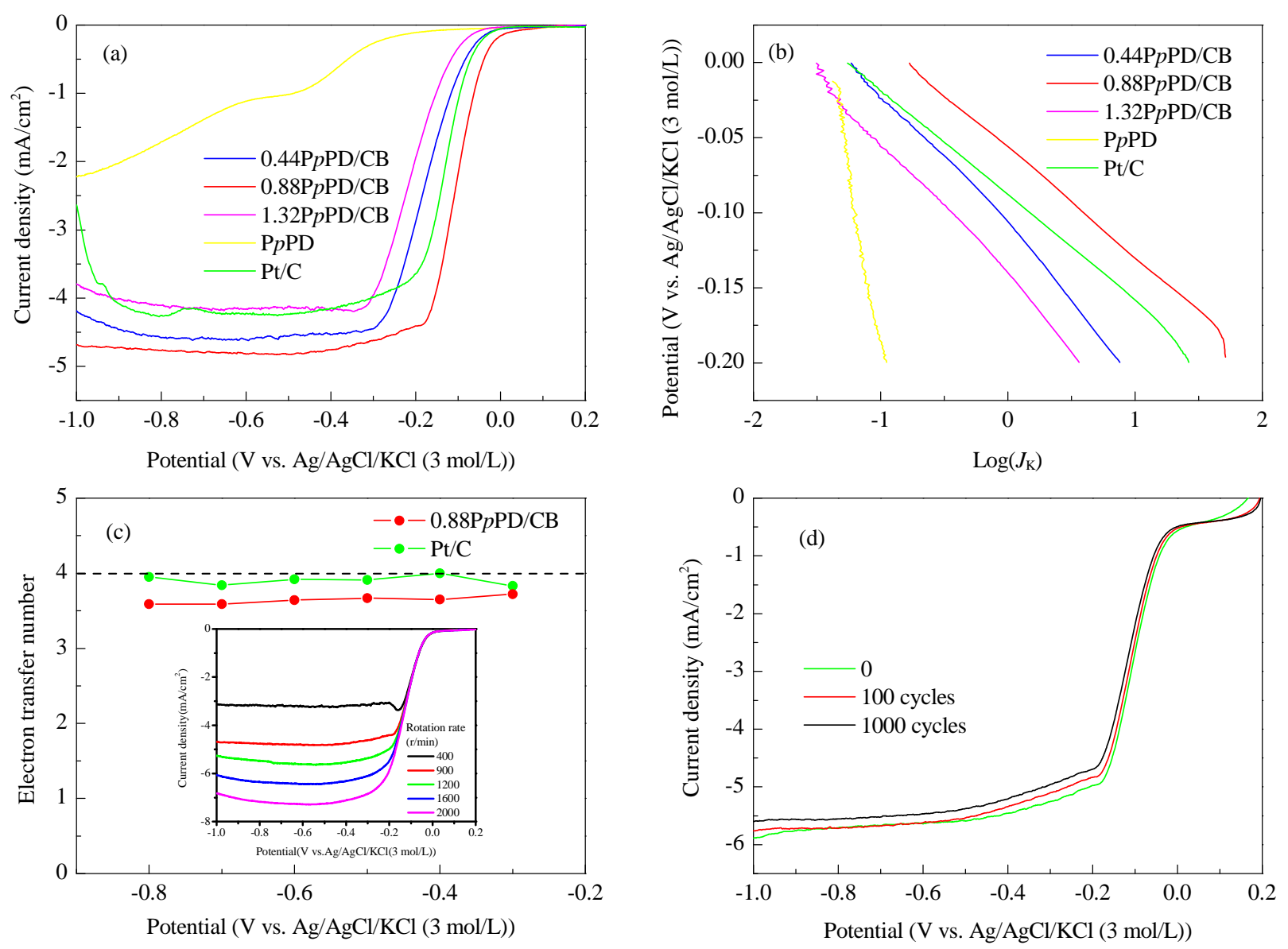

Fig. 3. RDE linear sweep voltammograms (a) of the prepared catalysts (catalyst loading: $820 \mu \mathrm{g} / \mathrm{cm}^{2}$ ) and Pt/C (catalyst loading: $250 \mu \mathrm{g} / \mathrm{cm}^{2}$ ); tafel plots (b) obtained from the RDE measurements; the dependence of the electron transfer number on the potential (c) for $0.88 \mathrm{P} p \mathrm{PD} / \mathrm{CB}$ and $\mathrm{Pt} / \mathrm{C}$ at various potentials (Inset shows the RDE voltammograms of $0.88 \mathrm{P} p \mathrm{PD} / \mathrm{CB}$ at various rotation rates); accelerated durability test data (d) for $0.88 \mathrm{P} p \mathrm{PD} / \mathrm{CB}$ after 100 and 1000 cycles. RDE data were recorded in $\mathrm{KOH}$ solution $(0.1 \mathrm{~mol} / \mathrm{L})$; electrode rotation speed $900 \mathrm{r} / \mathrm{min}$; scan rate 10 $\mathrm{mV} / \mathrm{s}$.

reduced almost completely to $\mathrm{OH}^{-}$through the 4-electron reduction process.

\subsection{Durability investigations}

To evaluate the electrochemical durability of the $0.88 \mathrm{P} p \mathrm{PD} / \mathrm{CB}$, accelerated durability tests using cyclic voltammograms ranging from -0.3 to $0.2 \mathrm{~V}$ at $50 \mathrm{mV} / \mathrm{s}$ in $\mathrm{O}_{2}$-saturated $\mathrm{KOH}$ solution $(0.1 \mathrm{~mol} / \mathrm{L})$ were carried out. It is evident from Fig. 3(d) that a slight change in the half-wave potential $(\sim 18$ $\mathrm{mV}$ ) is observed after 1000 cycles, indicating the good electrochemical stability of the $0.88 \mathrm{P} p \mathrm{PD} / \mathrm{CB}$. To evaluate the durability of this material, it was exposed to air for $30 \mathrm{~d}$. The results following this exposure show that the catalytic activity of the $0.88 \mathrm{P} p \mathrm{PD} / \mathrm{CB}$ decreased after air exposure; the current density at $-0.1 \mathrm{~V}$ decreased by $1.02 \mathrm{~mA} / \mathrm{cm}^{2}$ and the diffusion-limiting current density was also reduced (Fig. 4(a)). As previously discussed, platinum-based materials tend to oxidize upon exposure to air, generating a surface oxide layer. We believe that oxidation also occurs upon exposure of the $0.88 \mathrm{P} p \mathrm{PD} / \mathrm{CB}$ to the atmosphere, decreasing the ORR activity. XPS assessments were performed to determine the chemical composition and structure of the catalyst. As shown in Fig. 4(b), the oxygen content of the $0.88 \mathrm{P} p \mathrm{PD} / \mathrm{CB}$ increased by $1 \%$ (atomic fraction) following air exposure, while the $\mathrm{N}$ content decreased slightly. The increase in the oxygen content indicates the occurrence of an oxidation reaction, although this reaction cannot be directly attributed to atmospheric oxygen. Thus, in order to eliminate other factors, such as water vapor and carbon dioxide, we ran another experiment. Following heat treatment and cooling of the sample to below $100{ }^{\circ} \mathrm{C}$, the nitrogen atmosphere was transitioned to oxygen, exposing the $0.88 \mathrm{P} p \mathrm{PD} / \mathrm{CB}$ to high purity oxygen for $1 \mathrm{~h}$. XPS results reveal that the oxygen content of the $0.88 \mathrm{P} p \mathrm{PD} / \mathrm{CB}$ almost doubled after this oxygen exposure, and the $01 s$ spectrum in Fig. 4(d) clearly shows increases in the $\mathrm{C}=\mathrm{O}(531.2 \mathrm{eV})$ and $\mathrm{C}-\mathrm{O}(533 \mathrm{eV})$ components [8,27]. In subsequent RDE measurements, the ORR activity of the 0.88P $p$ PD/CB was found to have greatly decreased (Fig. 4(a)) after this oxygen exposure; the current density at $-0.1 \mathrm{~V}$ was only $0.29 \mathrm{~mA} / \mathrm{cm}^{2}$ and the diffusion-limiting current density was less than $4 \mathrm{~mA} / \mathrm{cm}^{2}$. These data demonstrate that exposing $0.88 \mathrm{P} p \mathrm{PD} / \mathrm{CB}$ to air allows oxygen to react with the catalyst, and this oxidation decreases the ORR activity. Therefore, the $0.88 \mathrm{P} p \mathrm{PD} / \mathrm{CB}$ should be protected from oxygen exposure to 

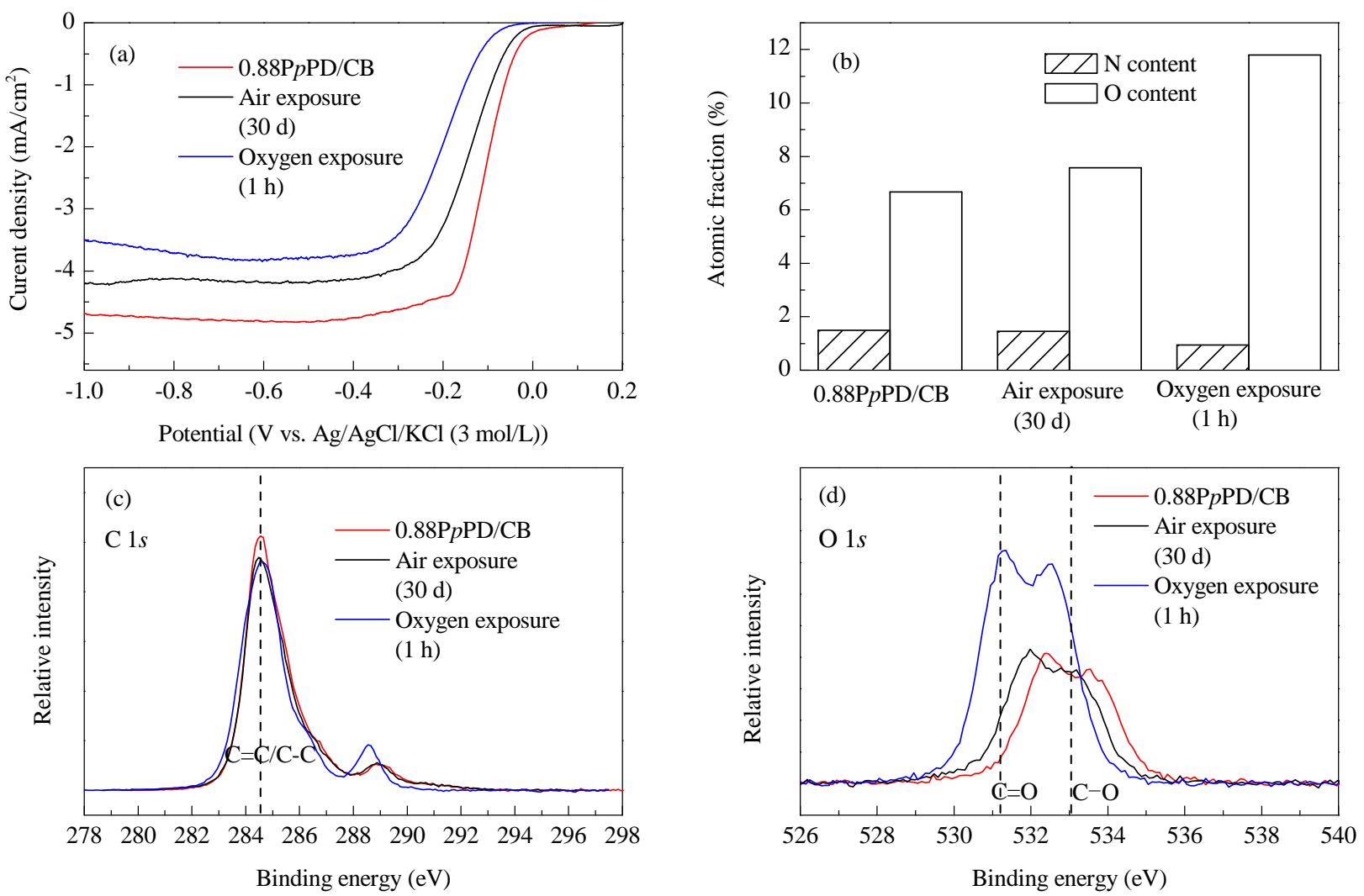

Fig. 4. RDE voltammograms (a) (KOH solution ( $0.1 \mathrm{~mol} / \mathrm{L})$; electrode rotation speed $900 \mathrm{r} / \mathrm{min}$; scan rate $10 \mathrm{mV} / \mathrm{s})$; the nitrogen and oxygen contents (b); $\mathrm{C} 1 \mathrm{~s}$ spectra (c); $01 s$ spectra (d) of the $0.88 \mathrm{P} p \mathrm{PD} / \mathrm{CB}$, following exposure to air for $30 \mathrm{~d}$ or to pure oxygen for $1 \mathrm{~h}$ after heat treatment.

preserve its catalytic ability.

\section{Conclusions}

In summary, nitrogen-doped carbon materials with high catalytic activity in alkaline solution were obtained via the pyrolysis of $\mathrm{P} p \mathrm{PD} / \mathrm{CB}$ composite. It was found that the exposure of this composite to the ambient atmosphere resulted in oxidation of the catalyst that in turn decreased the ORR activity. Thus stability in air must be taken into consideration when assessing the application of nitrogen-doped carbon materials as alternatives to platinum-based catalysts.

\section{References}

[1] B. C. H. Steele, A. Heinzel, Nature, 2001, 414, 345-352.

[2] M. Winter, R. J. Brodd, Chem. Rev., 2004, 104, 4245-4269.

[3] R. L. Liu, D. Q. Wu, X. L. Feng, K. Müllen, Angew. Chem. Int. Ed. , 2010, 49, 2565-2569.

[4] F. Jaouen, E. Proietti, M. Lefèvre, R. Chenitz, J. P. Dodelet, G. Wu, H. T. Chung, C. M. Johnston, P. Zelenay, Energy. Environ. Sci., 2011, 4, 114-130.

[5] K. P. Gong, F. Du, Z. H. Xia, M. Durstock, L. M. Dai, Science, 2009, 323, 760-764.

[6] J. Liang, Y. Zheng, J. Chen, J. Liu, D. Hulicova-Jurcakova, M. Jaroniec, S. Z. Qiao, Angew. Chem. Int. Ed., 2012, 51, 3892-3896.

[7] S. Maldonado, K. J. Stevenson, J. Phys. Chem. B, 2005, 109, 4707-4716.

[8] D. H. Guo, R. Shibuya, C. Akiba, S. Saji, T. Kondo, J. Nakamura, Sci- ence, 2016, 351, 361-365.

[9] S. Bhadra, D. Khastgir, Polym. Degrad. Stabil., 2008, 93, 1094-1099.

[10] Y. Zhang, X. D. Zhuang, Y. Z. Su, F. Zhang, X. L. Feng, J. Mater. Chem. A, 2014, 2, 7742-7746.

[11] Z. J. Zou, H. Cheng, J. Y. Wang, X. J. Han, Chin. J. Catal., 2015, 36, 414-424.

[12] Q. Wang, Z. Y. Zhou, Y. J. Lai, Y. You, J. G. Liu, X. L. Wu, E. Terefe, C. Chen, L. Song, M. Rauf, N. Tian, S. Q. Sun, J. Am. Chem. Soc., 2014, 136, 10882-10885.

[13] Y. F. Tang, B. L. Allen, D. R. Kauffman, A. Star, J. Am. Chem. Soc., 2009, 131, 13200-13201.

[14] G. Wu, K. L. More, P. Xu, H. L. Wang, M. Ferrandon, A. J. Kropf, D. J. Myers, S. Q. Ma, C. M. Johnston, P. Zelenay, Chem. Commun., 2013, 49, 3291-3293.

[15] V. Stamenkovic, B. S. Mun, K. J. J. Mayrhofer, P. N. Ross, N. M. Markovic, J. Rossmeisl, J. Greeley, J. K. Nörskov, Angew. Chem. Int. Ed., 2006, 45, 2899-2901.

[16] J. K. Nörskov, J. Rossmeisl, A. Logadottir, L. Lindqvist, J. R. Kitchin, T. Bligaard, H. Jonsson, J. Phys. Chem. B, 2004, 108, 17886-17892.

[17] E. Molaakbari, A. Mostafavi, H. Beitollahi, R. Alizadeh, Analyst, 2014, 139, 4356-4364.

[18] H. Beitollahi, I. Sheikhshoaie, Electrochim. Acta, 2011, 56, 10259-10263.

[19] Y. Y. Shao, G. P. Yin, Y. Z. Gao, J. Power Sources, 2007, 171, 558-566.

[20] C. H. Paik, T. D. Jarvi, W. E. O'Grady, Electrochem. Solid. State. Lett., 2004, 7, A82-A84.

[21] L. P. Zhang, Z. H. Xia, J. Phys. Chem. C, 2011, 115, 11170-11176. 


\title{
Graphical Abstract
}

Chin. J. Catal., 2016, 37: 1096-1102 doi: 10.1016/S1872-2067(15)61063-4

Investigation of the durability of a poly-p-phenylenediamine/carbon black composite for the oxygen reduction reaction

Xiaogang Su, Yingfang Yao, Juan Tian, Jianguo Liu *, Zhongwei Wang, Yong You, Lin Huang, Congping Wu Nanjing University

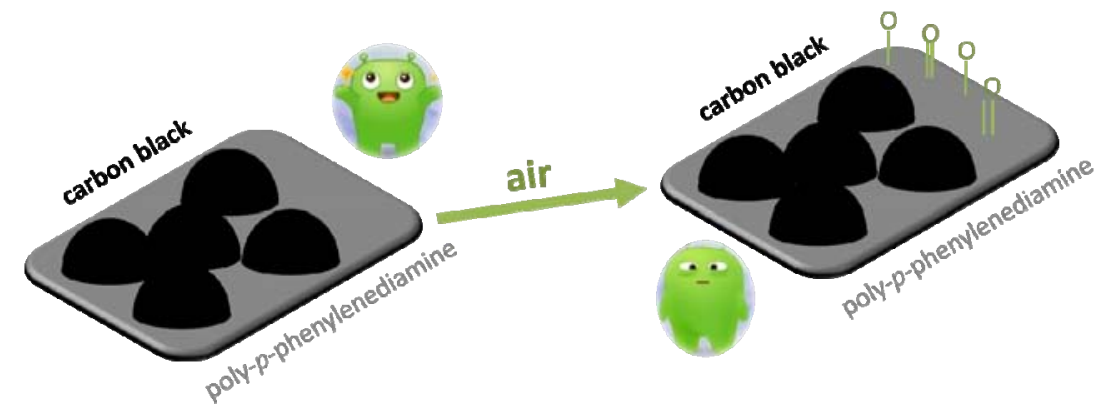

Exposing a poly- $p$-phenylenediamine/carbon black composite to air allows oxygen to react with it, and this oxidation leads to increases in the $\mathrm{C}=\mathrm{O}$ and $\mathrm{C}-\mathrm{O}$ components, thus the catalytic activity decreases.

[22] J. H. Zhu, S. Y. Wei, L. Zhang, Y. B. Mao, J. Ryu, N. Haldolaarachchige, D. P. Young, Z. H. Guo, J. Mater. Chem., 2011, 21, 3952-3959.

[23] G. Wu, K. L. More, C. M. Johnston, P. Zelenay, Science, 2011, 332, 443-447.

[24] S. A. Chen, G. W. Hwang, J. Am. Chem. Soc., 1995, 117, 10055-10062.
[25] H. Beitollahi, H. Karimi-Maleh, H. Khabazzadeh, Anal. Chem., 2008, 80, 9848-9851.

[26] J. S. Yang, J. J. Xu, Electrochem. Commun., 2003, 5, 306-311.

[27] C. Mattevi, G. Eda, S. Agnoli, S. Miller, K. A. Mkhoyan, O. Celik, D. Mastrogiovanni, G. Granozzi, E. Garfunkel, M. Chhowalla, Adv. Funct. Mater., 2009, 19, 2577-2583.

\section{聚对苯二胺和炭黑复合物作为高效的氧还原催化剂及其稳定性研究}

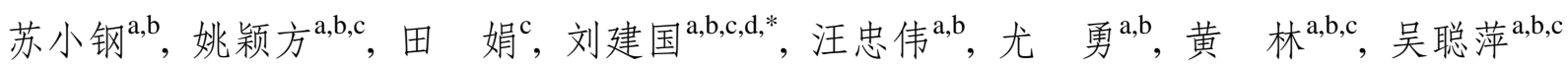 \\ a南京大学现代工程与应用科学学院, 江苏南京 210093 \\ b南京大学固体微结构物理国家重点实验室, 人工微结构科学与技术协同创新中心, 江苏南京 210093 \\ c南京大学昆山创新研究院, 江苏昆山 215347 \\ d 南京大学 (苏州) 高新技术研究院, 江苏苏州 215123
}

摘要: 近年来, 氮掺杂的碳材料作为碱性氧还原催化剂得到了研究者的广泛关注. 掺杂的 $\mathrm{N}$ 原子会影响 $\mathrm{C}$ 原子的自旋密 度和电荷分布, 导致碳材料表面产生 “活性位点”, 因此掺氮碳材料具有优秀的氧还原活性, 这已经在理论计算和实验中得 到了验证. 我们通过调节聚对苯二胺和碳黑的比例, 之后进行热解制备了一系列掺氮碳材料. 其中 $0.88 \mathrm{P} p \mathrm{PD} / \mathrm{CB}$ 样品具有 最好的氧还原活性, 其在 $\mathrm{KOH}$ 溶液 $(0.1 \mathrm{~mol} / \mathrm{L})$ 中的氧还原性能超过了商业碳载铂. 通过扫描电子显微镜表征, 发现碳球 聚集在聚对苯二胺的表面, 这主要是因为聚对苯二胺没有进行酸掺杂, 因此其水溶性比较差. 通过氮气的吸脱附表征, 发 现聚对苯二胺的比表面积很小, 而碳黑样品 (BP2000) 的比表面积很大. 因此, 随着聚对苯二胺量的增加, 聚对苯二胺/碳黑 复合物的比表面积逐渐降低. 另外, 聚对苯二胺表面几乎都是微孔, 而介孔和大孔主要来自于碳黑. 研究者认为, “活性位 点” 主要位于微孔内 (聚对苯二胺表面), 而介孔和大孔有利于物质的传输. 因此, 当聚对苯二胺和碳黑的比例合适时, 既有 大量的“活性位点”暴露, 又有足够的介孔和大孔进行物质传输, 所以 $0.88 \mathrm{P} p \mathrm{PD} / \mathrm{CB}$ 样品的氧还原活性最高.

但是, 对于掺氮碳材料来说, 一个主要的问题就是稳定性不足. 不管是电化学稳定性, 还是放置在空气中的稳定性, 掺 氮碳材料都比不上铂基催化剂, 这也阻碍了它们的大规模应用. 对于电化学稳定性, 很多文章都进行了报道, 但是很少有 文章报道掺氮碳材料在空气中的稳定性. 我们知道, 铂基材料之所以具有优异的氧还原活性, 是因为铂和氧气的结合能比 较合适, 既利于氧气吸附, 也利于之后氧气分子键的断裂. 但是, 当铂基材料放置在空气中, 氧气的吸附也会发生, 而且之 后会导致表面氧化层的形成. 所以铂基材料需要活化才能达到最好的催化性能. 对于掺氮碳材料, 放置在空气中会不会发 生氧化反应? 这对氧还原活性是否有影响? 为了研究掺氮碳材料在空气中的稳定性, 我们将 $0.88 \mathrm{P} p \mathrm{PD} / \mathrm{CB}$ 样品在空气中 
放置了一个月, 之后再进行电化学测试. 旋转圆盘电极测试表明, 在空气中放置了一个月后, $0.88 \mathrm{P} p \mathrm{PD} / \mathrm{CB}$ 样品的氧还原活 性降低了, 不管是半波电位还是极限电流密度都下降了. 之后我们对其进行了 $\mathrm{X}$ 射线光电子能谱检测, 发现在空气中放置 了一个月后其氧含量提高了 $1 \%$ (原子分数), 而氮含量几乎没有变化. 氧含量的提高证实了氧化反应的发生, 但不能直接归 结于空气中的氧气. 为了排除其他因素, 如水蒸气、二氧化碳等, 当热处理完成, 管式炉温度低于 $100{ }^{\circ} \mathrm{C}$ 时, 我们将高纯氮 气切换为高纯氧气, 一个小时后再取出样品. 电化学测试表明, 在氧气中暴露了一个小时后, $0.88 \mathrm{P} p \mathrm{PD} / \mathrm{CB}$ 样品的氧还原活 性极大地降低了, 而且 $\mathrm{X}$ 射线光电子能谱表明其氧含量提高了一倍, 接近 $12 \%$. 因此, 我们证实了氧气会和 $0.88 \mathrm{P} p \mathrm{PD} / \mathrm{CB}$ 样品反应, 导致样品的氧还原活性降低. 所以, 对于未来掺氮碳材料的大规模应用, 要考虑其在空气中的稳定性, 以及如何 避免和氧气接触.

关键词: 苯二胺; 炭黑; 复合结构; 氧气还原反应; 稳定性

收稿日期: 2016-01-06. 接受日期: 2016-02-02. 出版日期: 2016-07-05.

*通讯联系人. 电话: (025)83621219; 电子信箱: jianguoliu@nju.edu.cn

基金来源：国家自然科学基金(21476104); 江苏省自然科学基金杰出青年基金(BK20150009); 江苏省自然科学基金青年基金 (BK20150396); 江苏省软科学研究项目(BR2015009); 江苏省苏州市纳米技术专项(ZXG2013029); 江苏省优势学科以及江苏省青 蓝工程资助; 中央高校基本科研业务费.

本文的英文电子版由Elsevier出版社在ScienceDirect上出版(http://www.sciencedirect.com/science/journal/18722067). 